\title{
Standardization of plant growth regulators for successful tissue culture of sweet potato
}

\author{
Jahanara Parvin, Mahbub Robbani, Md. Fakhrul Hasan and Farhana Hoque
}

Department of Horticulture, Patuakhali Science and Technology University, Dumki, Patuakhali-8602, Bangladesh

\section{ARTICLE INFO}

Article history:

Received: 12 February 2018

Accepted: 07 July 2018

\section{Keywords:}

Sweet potato, Tissue culture, BAP Kinetin, IBA, NAA

\section{Correspondence:}

Mahbub Robbani

(mrobbanipstu@yahoo.com)

\begin{abstract}
The experiment was carried out during the period from June 2016 to January, 2017 at the Plant Biotechnology Laboratory, Department of Horticulture, Patuakhali Science and Technology University (PSTU) for in vitro regeneration of sweet potato. In this study, the nodal segment explants and different combinations of growth regulators were used for in vitro regeneration of sweet potato. BAP (6benzylamino purine) and KIN (Kinetin) were used for in vitro shoot regeneration and IBA (Indole-6Butyric Acid) with NAA (Naphthalene Acetic Acid) were used for in vitro root regeneration. The highest percentage of shoot initiation (91.30), the minimum number of days (9.00) for shoot initiation, the highest number of shoot/plantlet (11.00) and the highest shoot length $(4.38 \mathrm{~cm})$ was observed when nodal segment explants cultured on MS medium supplemented with BAP $1.5 \mathrm{mg} / \mathrm{L}+\mathrm{KIN} 0.1 \mathrm{mg} / \mathrm{L}$. On the other hand, the highest root initiation percentage (94.12), the minimum number of days (6.00) for root initiation, the highest number of root/plantlet $(9.33)$ and the highest root length $(11.13 \mathrm{~cm})$ was observed in the MS medium supplemented with IBA $0.5 \mathrm{mg} / \mathrm{L}+$ NAA $0.1 \mathrm{mg} / \mathrm{L}$. Regenerated plantlets were acclimatized for 5 days and adopted in soil by 6-7 days of transplantation.
\end{abstract}

\section{Introduction}

The sweet potato (Ipomoea batatas L.) is herbaceous dicotyledonous plant that belongs to the family Convolvulaceae. The center of origin of sweet potato is the tropical zone of the United States of America. It is a high yielding crop which is ranked second in the world after potato in terms of production (Deng et al., 2012). Sweet potato is very nutritious and an important source of complex carbohydrates, dietary fiber, vitamin A and C, proteins, iron, calcium, and beta carotene (Woolfe, 1992). The sweet potato normally propagated by vine cutting. The use of storage root and vine cuttings as a method for vegetative propagation is the cause for the accumulation of viruses from generation to generation which could result in declining of root yield and loss of superior genotypes. Aphids and whitefly vectors are the main causes of virus transmission (Moyer and Salazar, 1989; Gibson, 2004). This conventional system is also characterized by low multiplication rate, wastage of a large quantity of food material, absence of uniformity, risk of catching diseases. A regular supply of clean materials for planting is therefore necessary for sustainable production (Wang and Valkonen, 2008).

Multiplication of sweet potato provides a viable alternative to the conventional method of sweet potato propagation (Bachou, 2002) and could permit the production of relatively uniform plants on a massive scale in a shorter period of time (Mutandwa, 2008). Tissue culture techniques have opened a new frontier in agricultural science by addressing food security and agricultural production issues (Oggema et al., 2007).In tissue culture, the use of plant growth regulators play a vital role in influencing plant growth, differentiation and development for example, culture establishment, shoot initiation, rooting, embryogenesis etc. (Hobbie and Fatema, 1998).

Investigations on the utilization of tissue culture technology for exchange and conservation of germplasm of sweet potato were conducted (Jemal, 2009).The success in production of the healthy or disease free planting material of sweet potato is dependent on the reliability and efficiency of the regeneration protocol used. However, there is knowledge on a suitable regeneration protocol that would be efficient and reliable in regenerating rapidly the locally adapted sweet potato cultivars. Development of tissue culture regeneration protocol helps to reduce disease severity and hence produce healthy sweet potato plants in vitro that will improve healthy sweet potato planting materials. Therefore, the present study was undertaken to develop a suitable in vitro regeneration protocol and to determine the optimal concentrations and combinations of plant growth regulators for shoot and root initiation of sweet potato from nodal segment explants.

\section{Materials and Methods}

\section{Plant materials}

The research activities were conducted at the Plant Biotechnology Laboratory and Germplasm Center, Department of Horticulture, PSTU, during June 2016 to January 2017.The sweet potato variety cv. "BARI SP-2" 
(Kamalasundori) was used as a plant material in the present experiment. Nodal segments were collected as explants from sweet potato plants grown in Germplasm Center, Department of Horticulture, PSTU.

\section{Culture medium and explanting}

Murashige and Skoog (1962) medium was used as basal medium and supplemented with different concentrations and combinations of BAP (1.5, 2.5 and $3.5 \mathrm{mg} / \mathrm{L})$ and KIN (0.1 and $0.5 \mathrm{mg} / \mathrm{L})$ for shoot regeneration, IBA (0.2, 0.5 and $1.0 \mathrm{mg} / \mathrm{L})$ and NAA (0.1 and $0.2 \mathrm{mg} / \mathrm{L})$ for root initiation in the present investigation. All the plant growth regulators were dissolved in respective solution and store at $4^{\circ} \mathrm{C}$. Similarly stock solutions were prepared in prior to prepare culture medium and stored. The medium was prepared from the stock solutions, adjusted to $\mathrm{pH}$ 5.8, solidified with agar, dispensed $25 \mathrm{ml}$ per vessel and then sterilized at $121^{\circ} \mathrm{C}$ and 15 psi for $30 \mathrm{~min}$ in $50 \mathrm{ml}$ culture vials. After autoclaving, the culture vials containing the medium were allowed to cool down before inoculation. The surface sterilized dissected node explants were transferred into the laminar airflow cabinet and dissected by using sterile scalpel and were inoculated into the culture medium using sterile forceps.

\section{Culture environment}

The cultures were incubated at $25 \pm 1^{\circ} \mathrm{C}$ under the photoperiod of 16 hours in the growth chamber. The culture vessels with regenerated sweet potato plantlets were taken out from the growth chamber and kept in room temperature for 2-4 days to acclimate with room temperature. After 2-4 days hardened plantlets were taken out from culture vessel and roots were washed under running tap water to remove the agar and media. Then the plantlets were transferred to field soil.

The present experiment was laid out in the Completely Randomized Design (CRD) where each treatment replicated four times. Data on different parameters were collected and statistically analyzed to ascertain the significance of the experiment results. The means for all the treatments were calculated and 1 way analysis of variance (ANOVA) for all the characters were performed. The significance among the pair of means was evaluated at 5\% level of significance by Duncan's Multiple Range Test (Gomez and Gomez, 1984) by using MSTAT-C statistical package (Steel et al. 1997).

\section{Results and Discussion}

\section{In vitro shoot initiation}

The results on the effect of different concentration and combination of BAP and KIN for all parameters of shoot initiation were showed significant variability.

\section{Table 1. Effects of combined application of BAP and KIN on in vitro shoot initiation of sweet potato}

\begin{tabular}{|c|c|c|c|c|}
\hline BAP and KIN (mg/L) & $\begin{array}{c}\text { Shoot initiation } \\
\text { percentage }\end{array}$ & $\begin{array}{l}\text { Days required for } \\
\text { shoot initiation }\end{array}$ & $\begin{array}{c}\text { Number of shoot } \\
\text { per explant }\end{array}$ & $\begin{array}{l}\text { Shoot length } \\
\text { (cm) }\end{array}$ \\
\hline BAP 1.5 + KIN 0.1 & $91.30 \mathrm{a}$ & $9.00 \mathrm{f}$ & $11.00 \mathrm{a}$ & $4.38 \mathrm{a}$ \\
\hline BAP 2.5 + KIN 0.1 & $83.17 \mathrm{c}$ & $14.13 \mathrm{~d}$ & $6.57 \mathrm{c}$ & $3.88 \mathrm{~b}$ \\
\hline BAP 3.5 + KIN 0.1 & $74.00 \mathrm{e}$ & $19.61 \mathrm{~b}$ & $4.34 \mathrm{e}$ & $3.47 \mathrm{c}$ \\
\hline BAP $1.5+$ KIN 0.5 & $89.00 \mathrm{~b}$ & $12.14 \mathrm{e}$ & $8.17 \mathrm{~b}$ & $3.09 \mathrm{c}$ \\
\hline BAP $2.5+$ KIN 0.5 & $79.77 \mathrm{~d}$ & $17.00 \mathrm{c}$ & $5.47 \mathrm{~d}$ & $2.66 \mathrm{~d}$ \\
\hline BAP 3.5 + KIN 0.5 & $69.21 \mathrm{f}$ & $21.52 \mathrm{a}$ & $3.57 \mathrm{f}$ & $2.33 \mathrm{~d}$ \\
\hline Level of significance & * & * & * & * \\
\hline LSD $_{0.05}$ value & 0.35 & 0.40 & 0.32 & 0.41 \\
\hline CV (\%) & 0.29 & 1.71 & 3.30 & 8.33 \\
\hline
\end{tabular}

In a column, values having different letter (s) differ significantly at 5\% level of probability analyzed by DMRT, $\mathrm{BAP}=6$-benzylamino purine, $\mathrm{KIN}=$ Kinetin

Maximum shoot initiation percentage (91.30), minimum days for shoot initiation (9.00), highest number of shoot/explant (11.00) and maximum shoot length (4.38 $\mathrm{cm}$ ) was observed when nodal segment cultured on MS medium supplemented with BAP $1.5 \mathrm{mg} / \mathrm{L}+\mathrm{KIN} 0.1$ $\mathrm{mg} / \mathrm{L}$ (Table 1 and Plate 1 ). In contrast, MS medium containing BAP $3.5 \mathrm{mg} / \mathrm{L}+\mathrm{KIN} 0.5 \mathrm{mg} / \mathrm{L}$ produced the lowest value for all the parameters in case of in vitro shoot regeneration (Table 1). This results also supported by the findings of Wondimu et al. (2012) who obtained the best shoot proliferation on MS media supplemented with BAP $0.5 \mathrm{mg} / \mathrm{L}+\mathrm{KIN} 0.5 \mathrm{mg} / \mathrm{L}$.

Mengs (2014) reported that MS medium containing 0.5 $\mathrm{mg} / \mathrm{L}$ BAP concentration with lateral bud of sweet potato was the best for shoot regeneration. It took minimum time (10.66 days) for shoot initiation and the maximum number of shoot bud (10.98).

\section{In vitro root initiation}

Induction of healthy root system from the regenerated shoots is an essential part for successful development of plantlets.

Data in the Table 2 indicate that the maximum root initiation percentage (94.12), the minimum days for root initiation (6.00), the highest number of root/plantlet (9.33) and the maximum root length $(11.13 \mathrm{~cm})$ was found in the MS medium supplemented with IBA 0.5 $\mathrm{mg} / \mathrm{L}+$ NAA $0.1 \mathrm{mg} / \mathrm{L}$ (Plate 2). 
Plant growth regulators for successful tissue culture of sweet potato

Table 2. Effects of combined application of IBA and NAA on in vitro root initiation of sweet potato

\begin{tabular}{lcccc}
\hline \multicolumn{1}{c}{ IBA and NAA (mg/L) } & $\begin{array}{c}\text { Root initiation } \\
\text { percentage }\end{array}$ & $\begin{array}{c}\text { Days required for } \\
\text { root initiation }\end{array}$ & $\begin{array}{c}\text { Number of roots } \\
\text { per plantlet }\end{array}$ & $\begin{array}{c}\text { Root length } \\
\text { (cm) }\end{array}$ \\
\hline IBA 0.2 + NAA 0.1 & $87.26 \mathrm{c}$ & $10.78 \mathrm{~d}$ & $7.41 \mathrm{c}$ & $8.79 \mathrm{c}$ \\
IBA 0.5 + NAA 0.1 & $94.12 \mathrm{a}$ & $6.00 \mathrm{f}$ & $9.33 \mathrm{a}$ & $11.13 \mathrm{a}$ \\
IBA 1.0 + NAA 0.1 & $81.11 \mathrm{e}$ & $13.82 \mathrm{~b}$ & $5.54 \mathrm{e}$ & $5.93 \mathrm{e}$ \\
IBA 0.2 + NAA 0.2 & $84.01 \mathrm{~d}$ & $11.93 \mathrm{c}$ & $6.35 \mathrm{~d}$ & $7.73 \mathrm{~d}$ \\
IBA 0.5 + NAA 0.2 & $90.77 \mathrm{~b}$ & $8.45 \mathrm{e}$ & $8.53 \mathrm{~b}$ & $9.74 \mathrm{~b}$ \\
IBA 1.0 + NAA 0.2 & $75.14 \mathrm{f}$ & $15.24 \mathrm{a}$ & $4.39 \mathrm{f}$ & $4.07 \mathrm{f}$ \\
Level of significance & $*$ & $*$ & & $*$ \\
LSD 0.05 value & 0.52 & 0.32 & 0.34 & 0.73 \\
CV (\%) & 0.29 & 1.93 & 3.31 & 6.25 \\
\hline
\end{tabular}

In a column, values having different letter (s) differ significantly at 5\% level of probability analyzed by DMRT. IBA=Indole-6Butyric Acid, NAA=Naphthalene Acetic Acid
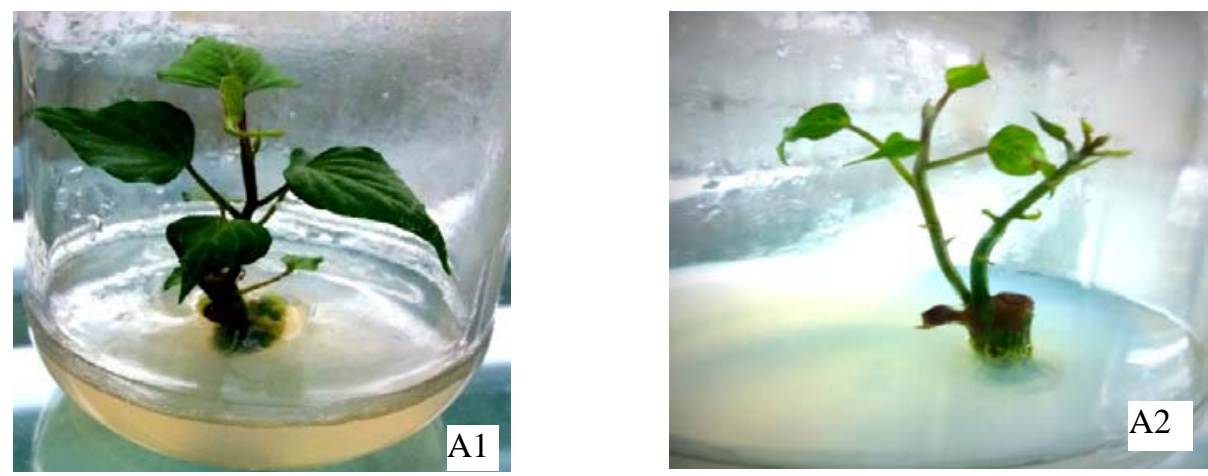

Plate 1. Shoot regeneration of sweet potato in MS medium supplemented with BAP $1.5 \mathrm{mg} / \mathrm{L}$ + KIN $0.1 \mathrm{mg} / \mathrm{L}$ (A1 and A2)
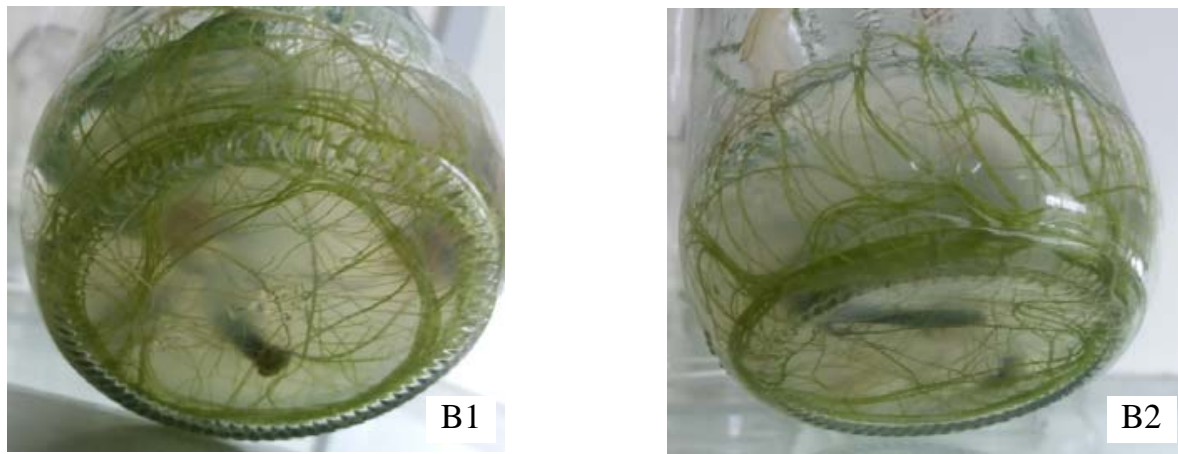

Plate 2. Root regeneration of sweet potato in MS medium supplemented with IBA $0.5 \mathrm{mg} / \mathrm{L}$ + NAA $0.1 \mathrm{mg} / \mathrm{L}$ (B1 and B2)
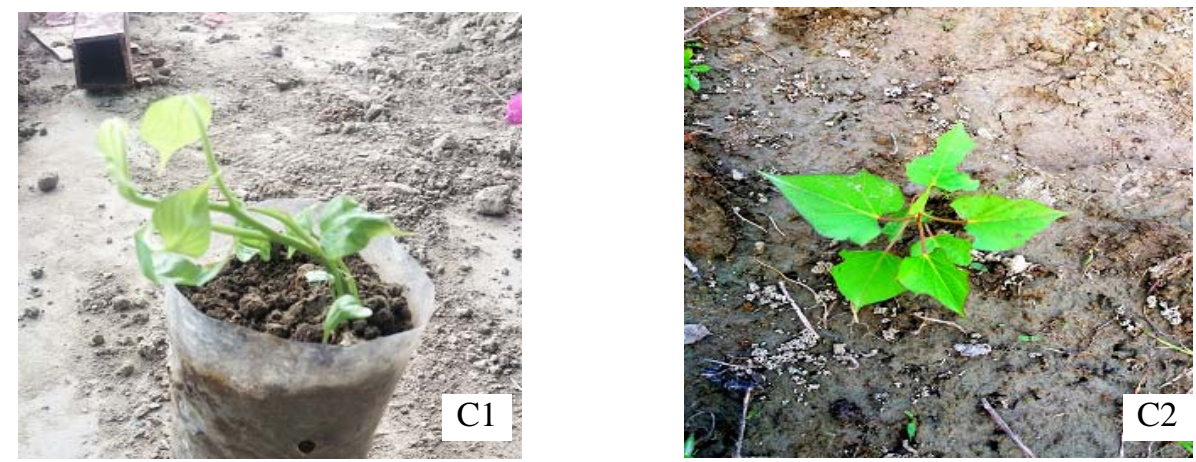

Plate 3. Plantlet in polybag (C1) and in field (C2) 
These results supported by the findings of Mengs (2014) who reported that $100 \%$ and $96.63 \%$ root formation were obtained on full strength MS media supplemented with $0.25 \mathrm{mg} / \mathrm{l}$ of IBA or $0.5 \mathrm{mg} / \mathrm{l}$ of NAA. Gao et al., (1999) obtained best result on medium containing $1.0 \mathrm{mg} / \mathrm{L}$ NAA for root differentiation and $0.1 \mathrm{mg} / \mathrm{L}$ NAA for root growth as optimum from leaf and stem segment explants.

This result also agrees with the findings of Ashrafuzzaman et al., (2009) who obtained maximum mean number of roots (12.00) per shoot on MS media supplemented with $1.0 \mathrm{mg} / \mathrm{L}$ NAA $+0.5 \mathrm{mg} / \mathrm{L}$ IBA. There might be a reason that combined concentration of IBA $0.5 \mathrm{mg} / \mathrm{L}+\mathrm{NAA} 0.1 \mathrm{mg} / \mathrm{L}$ accelerates more cell division and cell elongation of root than other treatment and thus cause more number of roots per plantlet.

\section{Acclimatization}

The plantlets with 6-7 leaf and well developed root system (5-6 roots) were ready for acclimatization. Replacing from growth chamber, plantlets were kept in room temperature for 4-5 days. Plantlets were removed from the test tubes with the forceps and transferred into a small earthen pot containing soil, sand and well rotten cowdung at 1:1:1 ratio. Immediately after transplantation, the plantlets were irrigated with fine spray of water and were kept them in shady area.

\section{Conclusion}

This study developed an efficient and reproducible regeneration protocol from the nodal segment explants of $I$. batatas. The explants can be easily obtained from established shoot cultures and do not require disinfection treatment. This protocol will therefore serve as an alternative method for conventional propagation and further investigations of $I$. batatas.

\section{Acknowledgement}

The author is grateful to the Ministry of Science and Technology of Peoples' Republic of Bangladesh and HEQEP for providing financial support to carry out the research work.

\section{References}

Ashrafuzzaman, F., Hossain, M., Ismail, M. R., Shahidul, M., Haque, M., Shahidullah, S. M. and Shahin, U. Z. 2009.
Regeneration potential of seedling explants of Ipomoea batatas L. J. Ap. Hort., 3:17-22.

Bachou, H. 2002. The nutrition situation in Uganda. Nutrition. 18: 356-358.

Deng, X. P., Cheng, Y. J., Wu, X. B., Kwak, S. S., Chen, W. and Egrinya, A. 2012. Exogenous hydrogen peroxide positively influences root growth and metabolism in leaves of sweet potato seedlings. Australian J. Crop Sci. 6:1572-1578.

Gao, F., Gong, Y. F. and Wang, X. J. 1999. High frequency induction of adventitious root differentiation and culture factor optimization in tissue culture of Ipomoea batatas. Southwest Agril. Sci. 21: 417-422.

Gibson, R. W. 2004. Working with farmers to control sweet potato virus diseases in east Africa. DFID crop protection program, a paper presented at the 9th triennial symposium of the International Society of Tropical Root Crops, pp. 28-30.

Gomez, K. A. and Gomez, A. A. 1984.Statistical procedure for Agricultural Research. John Wiley and Sons. New York. $2^{\text {nd }}$ ed. pp.64

Hobbie, M. I. and Fatema, M. 1998. Auxin: molecular genetic approaches in Arabidopsis. Plant Physio. Biochem. 36: 91102.

Mengs, B., 2014. In vitro Propagation of Sweet Potato (Ipomoea batatas Lam.) through Lateral bud Culture. M.Sc. Thesis, Department of Biotechnology, University of Haramaya, Ethiopia.

Moyer, W. J. and Salazar, F. L. 1989.Viruses and virus like diseases of sweet potato. Plant Disease73: 451-455.

Murashige, T. and Skoog, I. 1962.A revised medium for rapid growth and bioassays with tobacco tissue culture. Plant Physiology 15: 473-479.

Mutandwa, E., 2008. Performance of tissue cultured sweet potatoes among smallholders of Zimbabwe. J. Agrobiotechnol. Mnag. Econ. 11.

Jemal, N., 2009. Effectiveness of meristem culture and chemotherapy on the production of virus free Sweet potato (Ipomoea batatas). Addis Ababa University, Master of Science in Biotechnology pp 16-17.

Oggema, J. N., Kinyua, M.G., Ouma, J. P. and Owuoche, J. O. 2007. Agronomic performance of locally adapted sweet potato (Ipomoea batatasLam.) cultivars derived from tissue culture regenerated plants. African J. Biotech. 6: 14181425.

Steel, R. G. D., Torrie, J.H. and Dickie, D. A. 1997.Principles and procedures of statistics-a biometrics approach. McGrawHill Publishing Company, Toronto.

Wang, Q. C. and Valkonen, J. P. T. 2008.Elimination of two viruses which interact synergistically from sweet potato by shoot tip culture and cryotherapy. J. Virol. Meth. 154 135-45.

Wondimu, T., Feyissa, T. and Bedada, G. 2012.Meristem culture of selected sweet potato (Ipomoea batatas L.) cultivars to produce virus free planting maretial. J. Hort. Sci. Biotech. 87: 255-260.

Woolfe, J. A. 1992. Sweet potato, an untapped food resource (ed.). Cambridge University Press, new York, USA., 643 p. 